\title{
Pengembangan Handout Fisika Berbasis Team Assisted Individualization Untuk Meningkatkan Kemampuan Berpikir Kritis Peserta Didik SMA
}

\author{
Puji Astuti' ${ }^{1)}$, Asharii ${ }^{2)}$, Eko Setyadi Kurniawan ${ }^{3)}$ \\ Program Studi Pendidikan Fisika Universitas Muhammadiyah Purworejo \\ Jl. K.H.A Dahlan 3 Purworejo Telp. 0275-321494 \\ email: astuti31puji@gmail.com
}

Article Info: Submitted: 13/03/2018 | Revised: 30/03/2018 | Accepted: 21/04/2018

\begin{abstract}
Abstrak - Telah dilakukan penelitian pengembangan handout fisika berbasis team assisted individualization guna mengetahui kelayakan handout fisika berbasis team assisted individualization yang dikembangkan, respon peserta didik setelah menggunakan handout fisika berbasis team assisted individualization yang telah dikembangkan, dan peningkatan kemampuan berpikir kritis peserta didik. Jenis penelitian yaitu pengembangan yang mengacu pada model pengembangan ADDIE yaitu Analysis, Design, Development, Implementation dan Evaluation. Penelitian ini dilaksanakan di SMA Negeri 4 Purworejo dengan subjek penelitian berjumlah 32 peserta didik. Instrumen yang digunakan dalam penelitian ini adalah lembar validasi, angket respon peserta didik, lembar keterlaksanaan pembelajaran, dan tes hasil belajar. Berdasarkan penelitian diperoleh data hasil validasi handout fisika berbasis team assisted individualization dari tiga validator yaitu dua dosen ahli dan guru fisika mendapatkan nilai secara keseluruhan sebesar 3,35 termasuk dalam kategori cukup baik dan layak digunakan dalam proses pembelajaran. Respon peserta didik terhadap handout fisika berbasis team assisted individualization tahap penerapan diperoleh persentase 77,7\% dengan kategori baik. Peningkatan kemampuan berpikir kritis tahap penerapan diperoleh N-gain 0,581 dan termasuk kategori peningkatan sedang. Dengan demikian, handout fisika berbasis team assisted individualization yang dikembangkan dalam penelitian ini dikategorikan baik dan layak digunakan dalam pembelajaran serta dapat meningkatkan kemampuan berpikir kritis peserta didik.
\end{abstract}

Kata kunci: Handout, Team Assisted Individualization, Berpikir Kritis

\begin{abstract}
Research has been carried out on the development of team assisted individualization-based physics handouts to determine the feasibility of team-assisted individualization-based physics handouts developed, student responses after using the team-assisted individualization-based physics handouts that have been developed, and improvement in students' critical thinking skills. This type of research is a development that refers to the ADDIE development model, namely Analysis, Design, Development, Implementation, and Evaluation. This research was conducted at SMA Negeri 4 Purworejo with 32 research subjects. The instruments used in this study were validation sheets, student response questionnaires, learning achievement sheets, and learning achievement tests. Based on the research, the data obtained from the team-assisted individualization-based physics handout validation from three validators, namely two expert lecturers and physics teachers, received an overall score of 3.35 , included in the good enough category and feasible to be used in the learning process. Students' responses to the physicsbased handout team assisted individualization implementation phase obtained a percentage of $77.7 \%$ with a good category. Increased critical thinking skills of the application stage obtained an N-gain of 0.581 and included in the category of moderate improvement. Thus, a team assisted individualization-based physics handout developed in this study is categorized as good and suitable for use in learning and can improve students' critical thinking skills.
\end{abstract}

Keywords: Handout, Team Assisted Individualization, Critical Thinking Skill

\section{PENDAHULUAN}

Pendidikan merupakan pengetahuan, ketrampilan dan kebiasaan sekelompok orang yang bersifat umum dan turun temurun dari generasi ke generasi. Tahapan pendidikan pada umumnya yaitu prasekolah, Sekolah Dasar, Sekolah Menengah, dan Perguruan Tinggi. Pendidikan yang berkualitas akan membawa perubahan yang 
besar pada pola hidup manusia. Proses pembelajaran yang ideal yaitu pembelajaran sebagai proses belajar yang dibangun oleh pendidik untuk mengembangkan keaktifan, kemampuan berpikir dan meningkatkan pengetahuan serta penguasaan materi peserta didik terhadap materi dengan suatu sumber belajar[1].

Fisika merupakan cabang ilmu yang mempelajari tentang fenomena gejala- gelaja pada alam. Fisika merupakan salah satu mata pelajaran yang harus ditempuh oleh peserta didik dalam mengikuti pendidikan formal. Tujuan pembelajaran fisika dalam kerangka kurikulum 2013 yaitu menguasai konsep dan prinsip serta ketrampilan mengembangkan pengetahuan dan sikap percaya diri. Pada kenyataannya proses pembelajaran fisika yang ada disekolah lingkungan sekitar, menggunakan metode ceramah kemudian dilanjutkan dengan latihan soal, perlu adanya metode dan bahan ajar yang lebih mendukung lagi untuk tercapainya proses pembelajaran yang diharapkan. Dengan adanya hal tersebut peneliti beranggapan untuk mengembangkan bahan ajar berupa handout fisika dengan model pembelajaran kooperatif yaitu Team Assisted Individualization yang diharapkan dapat lebih meningkatkan kemampuan berpikir (berpikir kritis) peserta didik dan dan mampu untuk bekerja sama dengan rasa percaya diri.

\section{LANDASAN TEORI}

\section{A. A Handout}

Handout merupakan merupakan jenis media cetak selain modul yang mudah dikembangkan dan dapat dimanfaatkan dalam proses pembelajaran. Jika dibandingkan dengan modul, handout lebih sederhana, hal ini karen sesuai dengan fungsi handout sebagai ringkasan materi pelajaran [2]. Manfaat utama dari handout adalah meringkas materi. Handout berisi penjelasan yang lebih singkat, menjelaskan kaitan antartopik, memberi pertanyaan dan kegiatan pada para pembacanya, juga dapat memberikan umpan balik dan langkah tindak lanjut.

Penyusunan handout melalui beberapa langkah (1) melakukan analisis kurikulum, (2) menentukan judul handout dan menyesuaikan dengan kompetensi dasar serta materi pokok yang akan dicapai, (3) mengumpulkan referensi sebagai bahan penulisan, dengan megusahakan referensi yang digunakan terkini dan relevan dengan materi pokoknya, (4) mengusahakan agar kalimat yang digunakan untuk menulis tidak telalu panjang, (5) mengevaluasi hasil tulisan dengan cara dibaca ulang, bila perlu meminta orang lain untuk membacanya terlebih dahulu untuk mendapatkan masukan, (6) memperbaiki handout sesuai dengan kekurangan- kekurangan yang ditemukan, (7) menggunakan berbagai sumber belajar yang relevan [3].

\section{B. Team Assisted Individualization}

Team Assisted Individualization merupakan model pembelajaran kooperatif yang memiliki asas pemikiran dengan mengadaptasikan pembelajaran terhadap perbedaan individu yang berkaitan dengan kemampuan maupun pencapaian hasil belajar peserta didik. Palam model pembelajaran Team Assisted Individualization ini peserta didik ditempatkan dalam kelompok kecil yang terdiri dari 4 sampai 5 anak dan selanjutnya diberikan bantuan secara individu bagi peserta didik yang memerlukannya dengan harapan peserta didik dapat meningkatkan pikiran kritisnya, kreatif dan menumbuhkan rasa sosial yang tinggi [4].

Karakteristik yang membedakan model pembelajaran Team Assisted Individualization dengan model pembelajaran adalah (1) belajar bersama dengan teman, (2) selama proses belajar terjadi tatap muka antar teman, (3) saling mendengarkan pendapat diantara anggota kelompok, (4) belajar dari teman sendiri dalam kelompok. (5) belajar dalam kelompok kecil, (6) peserta didik aktif, dan yang paling utama adalah setiap peserta didik secara individual belajar materi pembelajaran yang sudah dipersiapkan oleh pendidik.

Komponen-komponen dari model pembelajaran team assisted individualization antara lain Teams, Placement Test. Curriculum Materials, Team Sutdy, Team Score and Team Recognition, Teaching Group, Fast Test, WholeClass Units [7]. 


\section{Kemampuan Berpikir Kritis}

Berpikir merupakan sebuah aktivitas yang selalu dilakukan oleh makhluk hidup khusunya manusia. Berpikir dan menyelesaikan suatu masalah merupakan hal yang paling penting. Berpikir merupakan salah satu daya paling utama dan menjadi ciri khas pembeda antara manusia dengan hewan. Manusia berpikir untuk menemukan pemahaman atau pengertian yang dikehendaki.

Berpikir kritis adalah sebuah kemampuan yang dimiliki setiap orang untuk menganalisis ide aau gagasan ke arah yang lebih spesifik untuk mengejar pengetahuan yang relevan tentang dunia dengan melibatkan evaluasi bukti. Kemampuan berpikir kritis sangat diperlukan untuk menganalisis suatu permasalahan hingga pada tahap pencarian solusi untuk menyelesaikan permasalahan tersebut. Orang- orang yang memiliki kemampuan berpikir kritis tidak hanya mengenal sebuah jawaban. Mereka akan mencoba mengembangkan kemungkinankemungkinan jawaban lain berdasarkan analisis dan informasi yang telah didapat dari suatu permasalahan. Berpikir kritis berarti berani melakukan proses penalaran terhadap suatu masalah sampai pada tahap kompleks [6].

Berpikir kritis juga merupakan berpikir dengan jelas dan secara rasional. Berpikir kritis melibatkan berpikir tepat dan sistematis serta mengikuti aturan logika dan penalaran ilmiah, diantara hal berbagai lainnya [5]. Aspek-aspek berpikir kritis yaitu : (1) mengidentifikasi masalah, (2) merumuskan hipotesis, (3) menganalisis, (4) menarik kesimpulan, (5) mengkomunikasikan, (6) berinteraksi dan bekerja sama.

D. Tinjauan Pustaka

Penelitian yang dilakukan oleh Dewi Ayu Kusumaningtias (2014) dengan topik Pengembangan Handout berbasis Multiple Intelligence untuk meningkatkan kemampuan berpikir kritis siswa kelas $\mathrm{X}$ SMA Muhammadiyah Wonosobo tahun pelajaran 2013/2014. Hasil penelitian ahli materi memperoleh rerata skor dari dari ahli materi sebesar 3,10 dan guru fisika sebesar 3,34 dengan interpretasi "Baik". Rerata keterlaksanaan pembelajaran dari dua observer 95,06 \% dengan interpretasi "Sangat Baik". Ketercapaian hasil belajar diperoleh rerata 78,5 dan untuk post- test secara klasikal sudah memenuhi KKM bernilai 70. Rerata skor respon perserta didik terhadap produk yang dikembangkan adalah 3,18 dengan interpretasi "Baik". Dengan demikian dapat disimpulkan handout fisika SMA kelas X berbasis Multiple Intelligence dapat digunakan sebagai alternatif bahan ajar fisika yang relevan [8].

Penelitian yang dilakukan oleh Yuliana Setya Nugraheni (2010) dengan topik Peningkatan antusias belajar IPA melalui pembelajaran kooperatif tipe Team Assisted Individualization (TAI). Hasil penelitian diperoleh peningkatan yang terjadi adalah $78,54 \%$ pada prasiklus, kemudian meningkat menjadi $79,12 \%$ pada siklus I, dan semakin meningkat pada siklus II yaitu $83,54 \%$. Berdasarkan peningkatan antusias belajar IPA tersebut maka dapat meningkatkan hasil belajar siswa dari $69 \%$ pada siklus I dan meningkat pada siklus II menjadi $80 \%$. Hasil penelitian ini dapat disimpulkan bahwa melalui pembelajaran kooperatif tipe Team Assisted Individualization (TAI) dapat meningkatkan antusias belajar IPA di MTs Negeri Kaleng Puring Kebumen [9].

Penelitian yang dilakukan oleh Angesti Febriana (2013) dengan topik Pengembangan Student Worksheet dengan pendekatan Problem Solving untuk mengoptimalkan kemampuan berpikir kritis pada materi Dinamika Rotasi dan Keseimbangan Benda Tegar SMA kelas XI. Hasil penelitian diperoleh rata-rata presentase hasil evaluasi student worksheet dari dosen ahli $70 \%$ dari guru fisika SMA 80,66\%, dari teman sejawat $81,33 \%$. Rata-rata skor post-test sebesar 88. Dengan demikian Student Worksheet dengan pendekatan Problem Solving layak digunakan sebagai bahan ajar Fisika SMA [10].

\section{METODE PENELITIAN/EKSPERIMEN}

Produk yang dikembangkan dalam penelitian ini adalah handout fisika berbasis Team Assisted Individualization untuk meningkatkan keampuan berpikir kritis. Desain penelitian ini diadaptasi dari model pengembangan ADDIE yang terdiri atas lima tahap pengembangan yaitu analysis 
(analisis), Design (perancangan), Development (pengembangan), Implementation (penerapan), Evaluation (mengevaluasi) [11]. Subyek dalam penelitian ini adalah peserta didik SMA Negeri 4 Purworejo yang berjumlah 32 peserta didik. Pengumpulan data dalam penelitian ini menggunakan metode observasi, wawancara, lembar validasi, metode angket, dan metode tes. Metode observasi digunakan untuk mengetahui keterlaksanaan pembelajaran di kelas menggunakan handout yang telah dikembangkan. Lembar validasi digunakan untuk melihat seberapa layak handout yang dikembangkan dapat digunakan dalam proses pembelajaran. Metode angket dilakukan untuk mengetahui respon peserta didik terhadap handout yang dikembangkan untuk meningkatkan kemampuan berpikir kritis. Sedangkan metode tes digunakan untuk memperoleh gambaran awal dan hasil belajar setelah menggunakan handout yang dikembangkan dan mengetahui peningkatan kemampuan berpikir kritis.

\section{HASIL DAN PEMBAHASAN}

A. Hasil Kelayakan Handout Fisika

Kelayakan bahan ajar berupa handout fisika dinilai oleh validator yaitu dosen ahli dan guru Fisika. Adapun hasilnya disajikan pada Gambar 1.

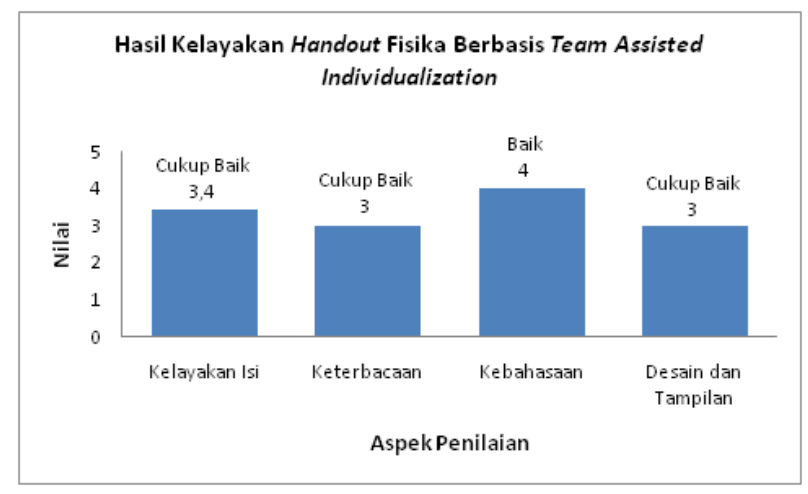

Gambar 1. Diagram Hasil kelayakan Handout Fisika Berbasis Team Assisted Individualization Oleh Dosen Ahli

Hasil validasi oleh dua dosen ahli dan guru fisika, penilaian oleh dosen ahli pada aspek kelayakan isi diperoleh skor 34 sehingga memperoleh persentase $85 \%$ dengan nilai 3,4 dengan kategori cukup baik. Aspek keterbacaan diperoleh skor 6 sehingga memperoleh persentase $75 \%$ dengan nilai 3 dengan kategori cukup baik. Aspek kebahasaan diperoleh skor 16 sehingga memperoleh persentase 100\% dengan nilai 4 dengan kategori baik. Aspek design dan tampilan diperoleh skor 12 sehingga memperoleh persentase $75 \%$ dengan nilai 3,0 dengan kategori cukup baik. Sehingga keseluruhan aspek mendapatkan nilai 13,4 sehingga reratanya 3,35 dengan kategori cukup baik.

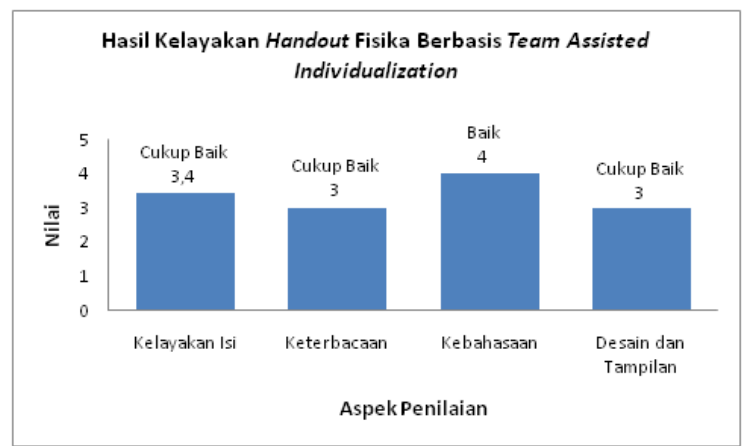

Gambar 2. Diagram Hasil Kelayakan Handout Fisika Berbasis Team Assisted Individualization Oleh Guru Fisika

Penilaian oleh guru fisika pada aspek kelayakan isi diperoleh skor 33 sehingga memperoleh persentase $82,5 \%$ dengan nilai 3,3 dengan kategori cukup baik. Aspek keterbacaan diperoleh skor 8 sehingga memperoleh persentase $100 \%$ dengan nilai 4 dengan kategori baik. Aspek kebahasaan diperoleh skor 15 sehingga memperoleh persentase $93,8 \%$ dengan nilai 3,75 dengan kategori baik. Aspek design dan tampilan diperoleh skor 14 sehingga memperoleh persentase $87,5 \%$ dengan nilai 3,5 dengan kategori cukup baik. Sehingga keseluruhan aspek mendapatkan nilai 14,55 sehingga reratanya 3,64 dengan kategori baik.

B. Hasil Peningkatan Kemampuan Berpikir Kritis Peserta Didik.

Peningkatan kemampuan berpikir kritis peserta didik dapat diketahui melalui hasil belajar peserta didik dan lembar observasi selama pembelajaran berlangsung. Hasil belajar peserta didik berupa skor prates dan postes yang disajikan pada Gambar 3. 


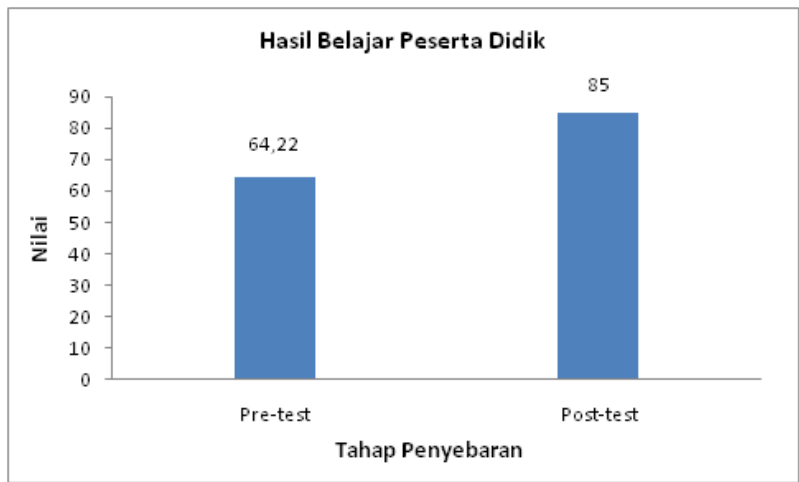

Gambar 3. Diagram Hasil Pre-test dan Post-test

Tahap penerapan hasil nilai pre-test menunjukkan nilai reratanya 64,22 dan nilai post-test menunjukkan bahwa semua peserta didik dinyatakan tuntas dengan nilai reratanya 85 sehingga persentase ketuntasan belajar peserta didik secara klasikal $100 \%$ dinyatakan tuntas memperoleh kriteria gain 0,581 dengan kategori sedang.

\section{Hasil Respon Peserta Didik Terhadap Handout Fisika} Berbasis Team Assisted Individualization

Respon peserta didik terhadap bahan ajar handout dalam kategori baik, hal ini ditunjukkan pada Gambar 4.

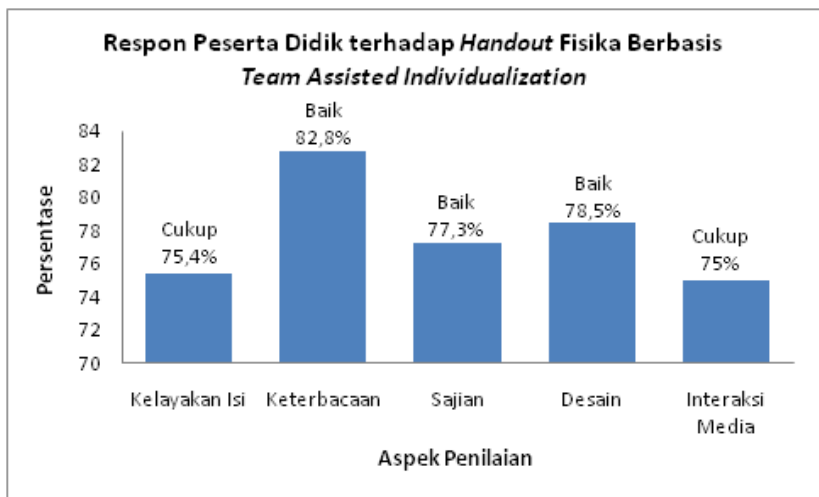

Gambar 4. Diagram Respon Peserta Didik terhadap Handout Fisika Berbasis Team Assisted Individualization

Data hasil respon peserta didik menggunakan handout fisika berbasis Team Assisted Individualization untuk meningkatkan kemampuan berpikir kritis peserta didik berdasarkan angket yang diisi sesuai keyakinan peserta didik. Terdapat 5 aspek yaitu aspek kelayakan isi, aspek keterbacaan, aspek sajian, aspek desain, dan aspek interaksi media. Berdasarkan klasifikasi dapat dilihat dalam Tabel 9 yaitu kriteria analisis pengubahan skor menjadi persentase, aspek kelayakan isi mendapatkan persentase 75,4 \% dengan klasifikasi cukup. Aspek keterbacaan mendapatkan persentase $82,8 \%$ dengan klasifikasi baik. Aspek sajian mendapatkan persentase $77,3 \%$ dengan klasifikasi baik. Aspek desain mendapat presentase 78,5\% dengan klasifikasi baik. Aspek interaksi media mendapatkan persentase $75 \%$ dengan klasifikasi cukup. Dengan demikian, keseluruhan aspek mendapatkan persentase $77,8 \%$, dapat disimpulkan bahwa respon respon peserta didik terhadap handout fisika berbasis Team Assisted Individualization adalah baik.

D. Keterlaksanaan Pembelajaran Menggunakan Handout Fisika Berbasis Team Assisted Individualization

Data hasil keterlaksanaan pembelajaran diperoleh dari dua orang observer pada tiap pertemuan. Uji reliabilitas pada pertemuan pertama diperoleh persentase $98,4 \%$, pertemuan kedua diperoleh persentase $98,5 \%$ dan pertemuan ketiga diperoleh persentase 98,4\%. Persentase yang didapatkan dari keseluruhan pertemuan adalah 98,45\%, adapun diagramnya ditunjukkan pada Gambar 5.

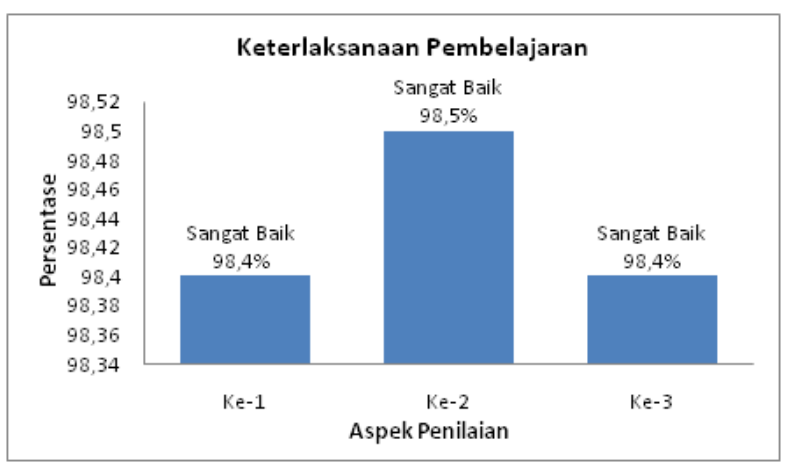

Gambar 5. Diagram Keterlaksanaan Pembelajaran

\section{E. Pembahasan}

Validasi kelayakan handout fisika oleh dua dosen ahli dan guru fisika mendapatkan nilai secara keseluruhan sebesar 3,36 dan termasuk kategori cukup baik, peningkatan hasil belajar diperoleh $N$-gain 0,581 dengan kategori peningkatan sedang. Peningkatan masih dalam kategori sedang dikarenakan beberapa peserta 
didik di kelas XI IPA 3 sudah memiliki kemampuan berpikir kritis yang baik. Setelah mendapatkan materi Teori Kinetik Gas beberapa peserta didik tersebut memperoleh nilai yang baik karena di atas nilai 80. Dengan demikian, handout fisika berbasis team assited individualization pada uji penerapan dapat meningkatkan kemampuan berpikir kritis peserta didik dengan ketegori peningkatan sedang.

\section{KESIMPULAN}

Berdasarkan hasil penelitian dan pengembangan validasi kelayakan handout fisika berbasis team assited oleh dua dosen ahli dan guru fisika mendapatkan nilai secara keseluruhan sebesar 3,35 termasuk kategori cukup baik sehingga layak digunakan dalam pembelajaran. Respon peserta didik terhadap handout fisika berbasis Team Assisted Individualization yang dikembangkan pada uji coba terbatas adalah baik dengan persentase $86 \%$, dengan kategori baik, pada tahap penerapan diperoleh persentase sebesar 77,7\% dengan kategori baik.

Peningkatan kemampuan berpikir kritis peserta didik dilihat dari nilai pre-test dan post-test pada tahap penerapan diperoleh $\mathrm{N}$-gain 0,581dan termasuk dalam kategori peningkatan sedang.

\section{UCAPAN TERIMA KASIH}

Ucapan terima kasih disampaikan SMA Negeri 4 Purworejo sebagai tempat penelitian

\section{PUSTAKA}

[1] M. Stemm and R. H. Katz, Measuring and reducing energy consumption of network interfaces in hand-held devices, IEICE Transactions on Communications, vol. E80-B, no. 8, 1997, pp. 1125-1131.

[2] F. Bennett, D. Clarke, J. B. Evans, A. Hopper, A. Jones and D. Leask, Piconet: Embedded mobile networking, IEEE Personal Communications Magazine, vol. 4, no. 5, 1997, pp. 8-15.

[3] M. R. Andrews, P. P. Mitra and R. deCarvalho, Tripling the capacity of wireless communication using electromagnetic polarization, Nature, vol. 409, 2001, pp. 316-318.

[4] S. M. Agarwall and A. Grover, Nucleotide Composition and Amino Acid Usage in AT-Rich Hyperthermophilic Species, The Open Bioinformatics Journal, Vol. 2, 2008, pp. 11-19.
[5] S. Verdu, Multi-user detection, Cambridge University Press, 1998.

[6] A. S. Prasad, Clinical and Biochemical Spectrum of Zinc Deficiency in Human Subjects, In: A. S. Prasad, Ed., Clinical, Biochemical and Nutritional Aspects of Trace Elements, Alan R. Liss, Inc., New York, 1982, pp. 5-15.

[7] L. Clare, G. Pottie and J. Agre, Self-organizing distributed sensor networks, Proceedings SPIE Conference Unattended Ground Sensor Technologies and Applications, vol. 3713, Orlando, April 1999, pp. 229237.

[8] W. Heinzelman, Application-specific protocol architectures for wireless networks, Ph.D. dissertation, Massachusetts Institute of Technology, Cambridge, 2000.

[9] L. Honeycutt, Communication and Design Course, 1998. Website: http://dcr.rpi.edu/commdesign/class1.html, diakses tanggal 3 November 2018. 